\title{
Short communication: inhibiting biofilm formation on paper towels through the use of selenium nanoparticles coatings
}

This article was published in the following Dove Press journal:

International Journal of Nanomedicine

22 January 2013

Number of times this article has been viewed

Qi Wang'

Thomas J Webster ${ }^{2}$

'Bioengineering Program, ${ }^{2}$ Department of Chemical Engineering, College of Engineering, Northeastern University, Boston, MA, USA
Correspondence: Thomas J Webster Northeastern University, 360 Huntington Avenue, Boston, MA 02115, USA

$\mathrm{Tel}+\mathrm{I} 6173736585$

Fax + I 6173732209

Email th.webster@neu.edu
Abstract: Bacterial infections are commonly found on paper towels and other paper products, leading to the potential spread of bacteria and consequent health concerns. The objective of this in vitro study was to introduce antibacterial properties to standard paper towel surfaces by coating them with selenium nanoparticles. Scanning electron microscopy was used to measure the size and distribution of the selenium coatings on the paper towels. Atomic force microscopy was used to measure the surface roughness of paper towels before and after they were coated with selenium nanoparticles. The amount of selenium precipitated on the paper towels was measured by atomic absorption spectroscopy. In vitro bacterial studies with Staphylococcus aureus were conducted to assess the effectiveness of the selenium coating at inhibiting bacterial growth. Results showed that the selenium nanoparticles coated on the paper towel surface were well distributed with semispherical geometries about $50 \mathrm{~nm}$ in diameter. Most importantly, the selenium nanoparticle-coated paper towels inhibited S. aureus growth by $90 \%$ after 24 and 72 hours compared with the uncoated paper towels. Thus, the study showed that nanoparticle selenium-coated paper towels may lead to an increased eradication of bacteria in a wider range of clinical environments and in the food industry, thus improving human health.

Keywords: selenium nanoparticles, paper towel, antibacterial, Staphylococcus aureus

\section{Introduction}

In the hospital environment, hand washing has been identified as the most significant manner towards preventing the spread of microbial infections, ${ }^{1,2}$ with hand drying as the critical last stage of the hand washing process. Among the three frequently used methods to dry hands (hot air dryers, cloth towels, and paper towels), paper towels have been recognized as the most hygienic method..$^{3-5}$ However, in some circumstances, eg, paper towels hanging in sink splash zones or those used to clean surfaces, paper towels have been considered as potential sources of bacteria contamination. ${ }^{6}$ Previously, studies evaluated the potential bacterial contamination of unused paper towels. ${ }^{7-9}$ In a hand washing experiment, participants who washed their hands with water and regular or antibacterial soap followed by drying with paper towels surprisingly had more bacteria on their hands after washing than before, which clearly indicated a possible bacterial transmission from paper towels. ${ }^{8}$ It was further demonstrated that a zigzag transfer of bacteria between paper towel dispensers and hands could take place if either one is contaminated. ${ }^{9}$ Besides paper towels that are used for hand drying, there are concerns for many other paper products in terms of bacterial contamination or infections, eg, food wrapping in the food industry, ${ }^{10}$ wallpaper in a doctor's suite, and filter paper in water purifying systems. ${ }^{11}$ All of these materials are prone to bacteria growth, and thus are sources for continual contamination. 
One of the most promising approaches towards preventing infections is coating paper products with antimicrobial materials. For example, $\mathrm{Hu}$ et al reported introducing antibacterial properties to filter paper by coating the paper with graphene oxide, which showed about a $70 \%$ inhibition to Escherichia coli growth after 2 hours. However, the graphene-based paper had mild cytotoxicity, resulting in $20 \%$ of healthy mammalian A945 cell death after 2 hours. ${ }^{12}$ Ghule et al studied the antibacterial activities of zinc oxide nanoparticle coated paper and results showed a significant decrease in bacteria counts after 24 hours. ${ }^{13}$ Besides zinc oxide nanoparticles, silver nanoparticles - which possess strong antibacterial properties - have also been loaded on filter paper for antibacterial purposes. ${ }^{14}$ But one major problem for zinc oxide, silver nanoparticles, and other metal-based materials is their toxicity to healthy cells (and the environment) due to the generation of reactive oxygen species. ${ }^{15,16}$ These materials may result in severe health problems when such coated paper products are used for food wrapping or clinical applications.

Compared with the above mentioned metal-based materials, selenium is considered to be healthier and less toxic to healthy cells. In fact, it is recommended by the Food and Drug Administration that adults intake about 53-60 micrograms of selenium per day as it is the requirement for 25 selenoproteins with selenocysteine at their active center. ${ }^{17}$ Therefore, in this study, for the first time, selenium nanoparticles were coated on normal paper towel surfaces through a quick precipitation method and the ability of selenium-coated paper towels to decrease bacteria functions were characterized. In addition, their effectiveness at preventing biofilm formation was tested in bacterial assays involving Staphylococcus aureus. The results showed for the first time that the selenium coatings successfully introduced antibacterial properties to paper towels, revealing a promising less toxic method to prevent bacterial infections on paper products that should be further explored for a wide range of applications.

\section{Material and methods}

\section{Materials}

Tork $^{\circledR}$ Advanced paper towels (MB550A; Svenska Cellulosa Aktiebolaget, Stockholm, Sweden) were cut into round chips (7.01 $\mathrm{mm}$ in diameter) and coated with selenium nanoparticles through a simple and quick precipitation reaction. The reaction involves glutathione (reduced form) (97\%, TCI America, Portland, OR, USA) and sodium selenite (99\%, Alfa Aesar, Ward Hill, MA, USA) mixed at a $4: 1$ molar ratio. Sodium hydroxide $(0.5 \mathrm{M})$ was added to bring the $\mathrm{pH}$ of the solution to the alkaline regimen, which favors the reaction. Selenium nanoparticles were formed immediately following the addition of sodium hydroxide as visualized by a color change of the reactant solution from clear white to clear red. The paper towel samples were coated for 30 seconds under $200 \mathrm{rpm}$ agitation to ensure a uniform coating. The coated substrates were rinsed in deionized water three times to remove the free, nonadherent selenium nanoparticles and remaining reactants.

\section{Materials characterization}

Scanning electron microscope (SEM; model F-700; Hitachi High Technologies, Tokyo, Japan) images of the paper towel substrate surfaces were taken to determine the size, coverage, and distribution of selenium nanoparticles. Before scanning the surface of a paper towel under SEM, the samples were coated with a $2 \mathrm{~nm}$ gold layer using a sputter coater (model K550; EMITech, Inc, Fall River, MA, USA) to make the samples conductive. The coverage of selenium nanoparticles on the paper towel surface was analyzed and calculated based on the SEM images using ImageJ (National Institutes of Health, Bethesda, MD, USA). An atomic force microscope (sharp-tipped cantilever, $\mathrm{K}=0.06 \mathrm{~N} / \mathrm{M}$, contact mode; MFP-3D ${ }^{\text {тм }}$ Stand Alone; Asylum Research, Santa Barbara, CA, USA) was used to demonstrate that there was an increase in surface roughness on paper towel samples after they were coated with selenium nanoparticles.

The coated samples were treated in $1 \mathrm{~mL}$ aqua regia for 30 minutes to dissolve all the selenium into a solution. After treatment, the solutions were collected in glass vials separately and then boiled to remove all the liquid. Next, $5 \mathrm{~mL}$ of $2 \%$ nitric acid was added into each vial to dissolve the residue, which contained all the selenium from the solution. After about 24 hours, the solutions were measured with atomic absorption spectroscopy (Furnace, AA600, Agilent Technologies, 710 Series, Santa Clara, CA, USA) to determine the concentration of selenium in each solution. SEM images of the treated films were taken to confirm that all the coated selenium was removed by aqua regia. Then, the amount of selenium on every sample was calculated based on the atomic absorption spectroscopy results. Measurements were completed in triplicate for both blank control samples (uncoated paper towels) and selenium-coated paper towel samples.

\section{Bacterial assays}

A bacteria cell line of $S$. aureus was obtained in freezedried form from the American Type Culture Collection (catalog number 25923; Manassas, VA, USA). The cells 

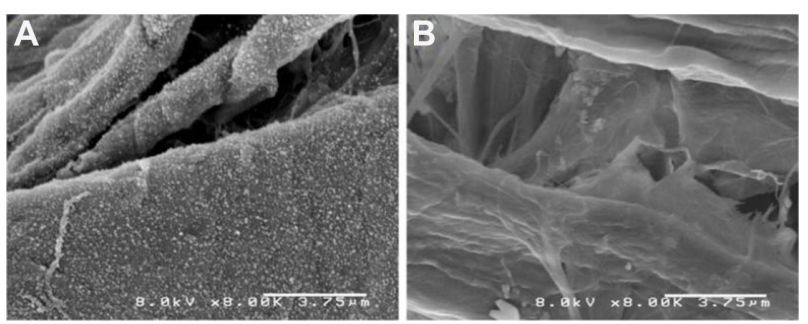

Figure I Scanning electron images of $(\mathbf{A})$ selenium-coated and $(\mathbf{B})$ uncoated paper towel samples.

Notes: The coating condition for selenium-coated samples was $0.5 \mathrm{M}$ sodium hydroxide for 30 seconds. The concentration of selenium on the paper towel, as measured by atomic absorption spectroscopy, was $69.00 \mathrm{~g} / \mathrm{m}^{2}$ for the selenium-coated paper towels and $0 \mathrm{~g} / \mathrm{m}^{2}$ for the uncoated paper towels.

were propagated in $30 \mathrm{mg} / \mathrm{mL}$ tryptic soy broth for 18 hours. A bacteria solution was prepared at a concentration of $10^{6}$ bacteria/mL, which was assessed by measuring the optical density of the bacterial solution using a standard curve correlating optical densities and bacterial concentrations. The optical densities were measured at $562 \mathrm{~nm}$ using a SpectraMax ${ }^{\circledR}$ M5 plate reader (Molecular Devices, Sunnyvale, CA, USA). Selenium-coated paper towel samples were rinsed with $75 \%$ ethanol for 20 minutes for sterilization purposes and left in the sterile Petri dishes for 30 minutes to completely dry. Then, the samples were transferred into a 24-well plate and treated with the prepared bacterial solutions $\left(10^{6} \mathrm{bacteria} / \mathrm{mL}\right)$ and cultured for either 24,48 , or 72 hours in an incubator $\left(37^{\circ} \mathrm{C}\right.$, humidified, $5 \%$ carbon dioxide). For those samples that were cultured for 48 and 72 hours, the media was changed with $1 \mathrm{~mL}$ sterile and fresh tryptic soy broth $(0.3 \mathrm{mg} / \mathrm{mL})$ every 24 hours. After the treatment, the samples were rinsed with a $10 \mathrm{mg} / \mathrm{mL}$ phosphate-buffered saline solution twice and placed into $1.5 \mathrm{~mL}$ microfuge tubes with $1 \mathrm{~mL}$ phosphate-buffered saline. These tubes were shaken at $3000 \mathrm{rpm}$ for 15 minutes on a vortex mixer to release the bacteria attached on the surface into the solution. Solutions with bacteria were spread on agar plates and bacteria colonies were counted after 18 hours of incubation. Bacterial tests were conducted in triplicate and repeated three times. Data were collected and the significant differences were assessed with the probability associated with a one-tailed Student's $t$-test. Statistical analyses were performed using Excel ${ }^{\circledR} 2010$ (Microsoft Corporation, Redmond, WA).

\section{Results and discussion Paper towel characterization}

Figure 1 shows the SEM images of the selenium-coated paper towels (Figure 1A) and uncoated paper towels (Figure 1B). On the selenium-coated paper towel samples, the selenium nanoparticles were well distributed and completely covered the surface. Some of the selenium nanoparticles were also observed in the fiber structure in contrast to the top surface. The diameters for most of the selenium particles were around $50 \mathrm{~nm}$. For the uncoated paper towel, there were no particles observed. The atomic force microscope images showed that the root mean square (scan area $=10 \mu \mathrm{m} \times 10 \mu \mathrm{m}$ ) roughness of the paper towel surface increased from $15.89 \mathrm{~nm}$ (Figure 2B) to $31.14 \mathrm{~nm}$ (Figure 2A) after being coated with selenium nanoparticles. Thus, the selenium nanoparticles were successfully coated on the paper towels and the large surface area of the selenium-coated fibrous paper towel surface increased the exposure of selenium.

According to the atomic absorption spectroscopy results, the concentration of the selenium nanoparticles on the coated
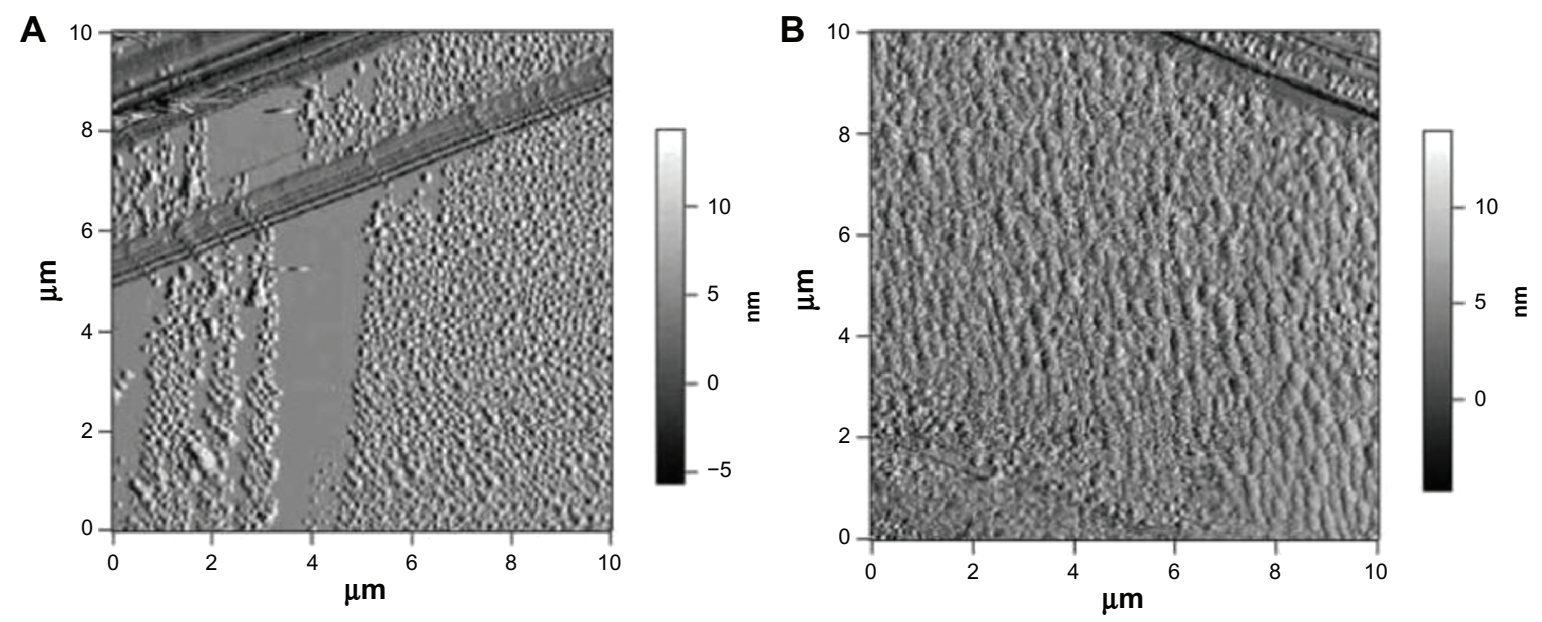

Figure 2 Atomic force microscope images and root mean square (scan area $=10 \mu \mathrm{m} \times 10 \mu \mathrm{m})$ roughness of $(\mathbf{A})$ selenium-coated and $(\mathbf{B})$ uncoated paper towel surfaces. Note: The surface of the selenium-coated samples had a root mean square roughness of $31.14 \mathrm{~nm}$ and the surface of the uncoated samples had a root mean square roughness of $15.89 \mathrm{~nm}$. 


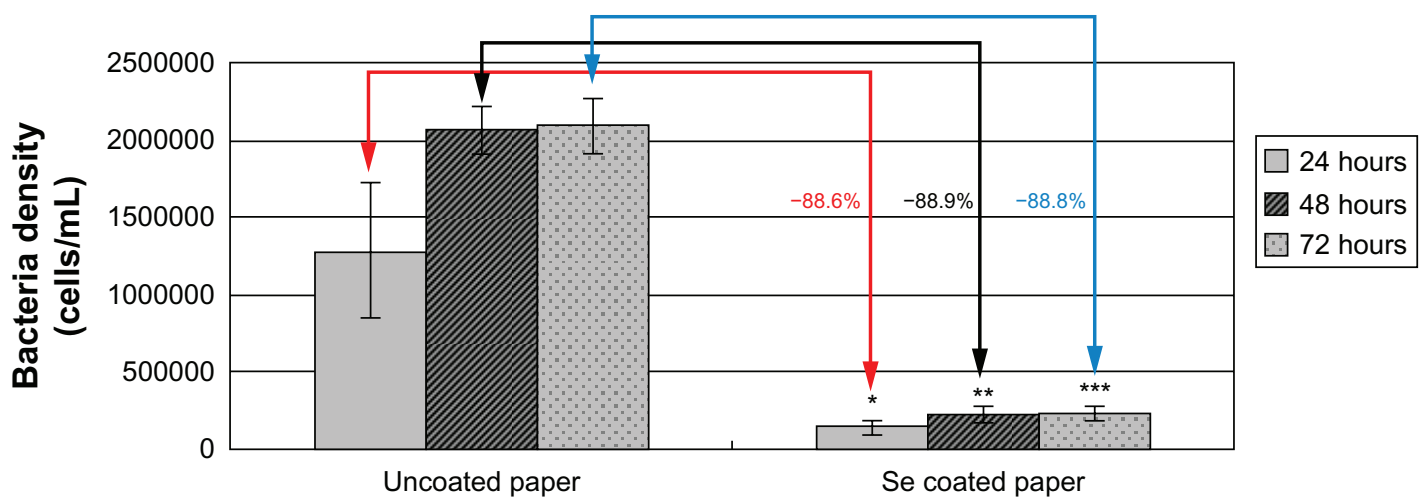

Figure 3 Bacteria (Staphylococcus aureus) growth on the surface of uncoated and selenium-coated paper towels.

Notes: Paper towel samples were treated with bacteria (S. aureus) in $0.03 \%$ tryptic soy broth and were incubated for 24,48 , or 72 hours. The control group is the uncoated paper towels. Data is represented as mean \pm standard deviation, $\mathrm{n}=3$; * $\mathrm{P}<0.02$ compared with the control group (uncoated paper) after 24 hours; ** $<0.002$ compared with control group after 48 hours; $* * * P<0.002$ compared with the control group after 72 hours.

Abbreviation: Se, selenium.

paper towel surface was $69.00 \mathrm{~g} / \mathrm{m}^{2}$. This concentration is about four times larger than the concentration of selenium on the coated polycarbonate surfaces under the same coating conditions published in a previous study. ${ }^{18}$ The reason was that the fibrous structure of the paper towel significantly increased surface area to allow for more selenium nanoparticle deposition.

\section{Bacterial assays}

Most importantly, based on the bacterial assays, the seleniumcoated paper towel samples significantly inhibited biofilm formation compared with uncoated paper towel samples. As seen in Figure 3, the selenium-coated paper towels had $88.6 \%, 88.9 \%$, and $88.8 \%$ less bacteria attached than the uncoated paper towels after 24,48 , and 72 hours, respectively. Moreover, from the 24-hour culture time to the 48-hour culture time, there was an increase in bacteria numbers on uncoated paper towel samples, but was constant to the 72-hour culture time, implying that the uncoated paper towel was saturated by bacteria after 48 hours of treatment. In contrast, the bacteria numbers on the selenium-coated paper towels remained at a low level, ie, not increasing from 24 to 48 to 72 hours, indicating successful inhibition of bacterial growth.

In the bacterial assays on polycarbonate samples in a previous study, there were distinct increases in bacteria numbers from 24 hours to 48 hours on all the coated samples, which indicated that after 48 hours, bacteria growth was not completely inhibited by the selenium coatings on polycarbonate ${ }^{18}$ However, Figure 2 showed that the selenium coatings on paper towel samples almost completely inhibited bacterial growth after 48 hours of treatment. The reason was that the amount of coated selenium nanoparticles on the polycarbonate samples was much smaller than the amount on the paper towel samples. Thus, the surface with more selenium nanoparticles revealed a stronger ability to prevent biofilm formation, especially when the bacteria in the biofilm propagated quickly. Overall, the bacteria growth and biofilm formation on paper towels were successfully inhibited after being coated with selenium nanoparticles.

\section{Conclusion}

In conclusion, the selenium precipitation process used was an easy and quick method to coat selenium nanoparticles on paper towels, and the selenium coatings significantly inhibited the growth of $S$. aureus on the surface of paper towels after 24, 48, and 72 hours. The effectiveness of bacteria inhibition reached about $90 \%$ for all three different periods of treatment compared with the uncoated paper towels. Thus, this study suggests that selenium nanoparticle coatings could be used as an effective way to decrease $S$. aureus infections on paper products, which might have potentially important applications in the food packaging industry, medicine, and in clinical environments.

\section{Acknowledgments}

The authors thank Dr Justin Seil for help with the bacteria experiment. They also thank Dr Vera Fonseca for help with the atomic force microscope images.

\section{Disclosure}

The authors report no conflicts of interest in this work.

\section{References}

1. Garner JS, Favero MS. CDC guideline for handwashing and hospital environmental control, 1985. Infect Control. 1986;7(4):231-243.

2. McGuckin M. Improving handwashing in hospitals: a patient education and empowerment program. LDI Issue Brief. 2001;7(3):1-4. 
3. Guzewich J, Ross MP. Evaluation of Risks Related to Microbiological Contamination of Ready-to-Eat Food by Food Preparation Workers and the Effectiveness of Interventions to Minimise Those Risks. Silver Spring, MD: Food and Drug Administration; 1999.

4. Boyce JM, Pitter D; Healthcare Infection Control Practices Advisory Committee; HICPAC/SHEA/APIC/IDSA Hand Hygiene Task Force. Guideline for hand hygiene in healthcare settings. MMWR Recomm Rep. 2002;51(RR-16):1-44.

5. Blackmore M . Hand drying methods. Nurs Times. 1987;83(37):71-74.

6. Hattula JL, Stevens PE. A descriptive study of the handwashing environment in a long-term care facility. Clin Nurs Res. 1997;6(4): 363-374.

7. Griffith CJ, Malik R, Cooper RA, Looker N, Michaels B. Environmental surface cleanliness and the potential for contamination during handwashing. Am J Infect Control. 2003;31(2):93-96.

8. Gendron LM, Trudel L, Moineau S, Duchaine C. Evaluation of bacterial contaminants found on unused paper towels and possible postcontamination after handwashing: a pilot study. Am J Infect Control. 2012;40(2):e5-e9.

9. Harrison WA, Griffith CJ, Ayers T, Michaels B. Bacterial transfer and cross-contamination potential associated with paper-towel dispensing. Am J Infect Control. 2003;31(7):387-391.

10. Rodriguez A, Batlle R, Nerin C. The use of natural essential oils as antimicrobial solutions in paper packaging. Part II. Prog Org Coat. 2007;60(1):33-38.
11. Yokota H, Tanabe K, Sezaki M, et al. Arsenic contamination of ground and pond water and water purification system using pond water in Bangladesh. Eng Geol. 2001;60(1-4):323-331.

12. $\mathrm{Hu} \mathrm{W}$, Peng $\mathrm{C}$, Luo W, et al. Graphene-based antibacterial paper. $A C S$ Nano. 2010;4(7):4317-4323.

13. Ghule K, Ghule AV, Chen BJ, Ling LC. Preparation and characterization of $\mathrm{ZnO}$ nanoparticles coated paper and its antibacterial activity study. Green Chem. 2006;8(12):1034-1041.

14. Tankhiwale R, Bajpai SK. Graft copolymerization onto cellulose-based filter paper and its further development as silver nanoparticles loaded antibacterial food-packing material. Colloids Surf B Biointerfaces. 2009; 69(2):164-168.

15. Xia T, Kovochich M, Liong M, et al. Comparison of the mechanism of toxicity of zinc oxide and cerium oxide nanoparticles based on dissolution and oxidative stress properties. ACS Nano. 2008;2(10): 2121-2134.

16. Foldbjerg R, Olesen P, Hougaard M, Dang DA, Hoffman HJ, Autrup H. PVP-coated silver nanoparticles and silver ions induce reactive oxygen species, apoptosis and necrosis in THP-1 monocytes. Toxicol Lett 2009;190(2):156-162.

17. Kryukov GV, Castellano S, Novoselov SV, et al. Characterization of mammalian selenoproteomes. Science. 2003;300(5624):1439-1443.

18. Wang Q, Webster TJ. Nanostructured selenium for preventing biofilm formation on polycarbonate medical devices. J Biomed Mater Res A. 2012;100(12):3205-3210.
International Journal of Nanomedicine

\section{Publish your work in this journal}

The International Journal of Nanomedicine is an international, peerreviewed journal focusing on the application of nanotechnology in diagnostics, therapeutics, and drug delivery systems throughout the biomedical field. This journal is indexed on PubMed Central, MedLine, CAS, SciSearch $₫$, Current Contents $₫ /$ Clinical Medicine,

\section{Dovepress}

Journal Citation Reports/Science Edition, EMBase, Scopus and the Elsevier Bibliographic databases. The manuscript management system is completely online and includes a very quick and fair peer-review system, which is all easy to use. Visit http://www.dovepress.com/ testimonials.php to read real quotes from published authors. 